\title{
The Study of Export-Import Logistics Operation Competence of Thai Employee for Asian Economic Community
}

\author{
Natepanna Yavirach \\ Department of Management, Faculty of Business Administration \\ Rajamangala University of Technology, Thanyaburi, Thailand \\ E-mail: natepanna@rmutt.ac.th
}

\begin{abstract}
Received: July 15, $2016 \quad$ Accepted: August 1, $2016 \quad$ Published: August 2, 2016
doi:10.5296/csbm.v3i2.9836 URL: http://dx.doi.org/10.5296/csbm.v3i2.9836
\end{abstract}

\begin{abstract}
This research was conducted to support the opening of the Asian Economic Community through the import-export logistic management operation of Thai employee competence. This approach is an innovative concept in Thailand with regards to the application of standard practices for occupation competency in logistic industries. This is the first time of Thai employee competency standard measurement. This can be ensured by obtaining a qualification test and certification from The Institute of Thailand Professional Qualification Standard Institute. Export-import's competency standard collected by using focus groups from top management and expertise employees in terms of export and import operation.

The research objective is to identify the standard competence of workers for export and import custom operation with the standard practice in terms of the entrepreneurial requirements. Furthermore, export and import competency standard be practiced for internationally as ISO 17024 standardization. As well as export and import operation standards with AEO international operations for the Asian Economic Community in 2016.

The research scope of the study related to custom clearance and custom broker employee in term of standard of occupation competency by using the Functional Analysis, Functional Map which consists of Key Purpose, Key Role and Key Function in relation to the unit of competence which consists of Element of competency, Performance Criteria, Range Statement, Evidence Requirement and Assessment Guidance and setting the competency level form for each career.
\end{abstract}

Keywords: Competency Standard, Professional Qualification, Export-Import, Logistic 
Operation, Competence, Custom Broker 2016, Vol. 3, No. 2 


\section{Introduction}

The study of import-export logistic operation competence standard professional qualifications is first time of Thai context. The advantages of export and import competency of employees enhance Thai higher performance in the export-import company. The components of professional standards refer to the international standard of competency such as Singapore, Hong Kong, Australia etc. adapt to Thailand Professional Qualification Institute of the Thai Government in order to develop a national system of qualified professionals and ISO 17024. The research result of export and import competence standard is approval and accepted by the expertise and high experience committee from export and import operation, university and export-import Company. The research objective is identified qualifications and the knowledge of export-import operation of employee for professional qualifications standards. The advantages of this study is to provide professional qualifications of export-import operation career to ensure performance in accordance with professional practice and to increase the capacity of human resources for the ASEAN Community and create added value to the country's economic sustainability.

\section{Objectives of the Research}

To encourage and support the occupation related to logistic management.

To prepare the network for developing and publishing professional standards and professional qualifications.

To promote the system of professional qualifications and standards of the profession duly recognized and accepted in all sectors.

To contribute to the curriculum development in teaching the logistics management and to meet the needs of enterprises.

To contribute to the establishment of a logistics tests.

To increase the competitiveness of the logistics system in Asian region in accordance to international standards.

\section{Literature Review}

The background of study and theoretical framework of professional qualification is National Vocational Qualification Specification standard competency (Fento, 2000). NVQI NVQ's are competence-based qualifications. The five levels of NVQ are defined as having the following competencies: Level 1-Competence, which involves the application of knowledge and skills in the performance of a range of varied work activities most of which may be routine and predictable. Level 2-Competence, which involves the application of knowledge and skills in a significant range of varied work activities, performed in a variety of contexts. Some of the activities are complex or non-routine, and there is some individual responsibility or autonomy. Collaboration with others, perhaps through membership of a work group or team, may often be a requirement. Level 3-Competence, which involves the application of knowledge and skills in a broad range of varied work activities performed in a wide variety of contexts and 
most of which are complex and non-routine. There is considerable responsibility and autonomy, and control or guidance of others is often required. Level 4-Competence, which involves the application of knowledge and skills in a broad range of complex, technical, or professional work activities performed in a wide variety of contexts and with a substantial degree of personal responsibility and autonomy. Responsibility for the work of others and the allocation of resources is often present. Level 5-Competence, which involves the application of skills and a significant range of fundamental principles and complex techniques across a wide and often unpredictable variety of contexts. Very substantial personal autonomy and often a significant responsibility for the work of others and for the allocation of substantial resources feature strongly, as do personal accountabilities for analysis and diagnosis, design, planning, execution and evaluation. Furthermore, national qualification framework of qualification specification (NQF) (2015) is used in this study.

\section{Research Methodology}

The gathering of research data includes a comprehensive observation of different range of occupations and professional associations related to exports and imports. Coordination with operators, professional staff, Government agencies, and private organizations are involved. The data collected from the working group committee who is the career expertise in export and import. Qualitative technique by using in-depth interview and focus group to recognize the knowledge, skills, and attribute of competencies of export-import employee. The study of the professional occupation in, United Kingdom, Singapore and Hong Kong are the background of export-import professional competency as globally.

In term of qualitative research methodology technique is using technical analysis functions (Functional Analysis / occupational analysis) by the coverage levels ranging from the primary to advance standard of competency that divided into five levels. Furthermore, Workshop Working Group committee is to prepare a functional diagram (Functional Map) consists of primary (Key Purpose) main role (Key Role) main function (Key Function) and workshops, working groups to prepare the unit performance (Unit of Competence) contain performance sub (Element) performance criteria (Performance Criteria) Range (Range Statement) evidence that requires both proof of performance, and evidence of knowledge (Evidence Requirement.) Evaluation (Assessment Guidance) and determine the performance of each profession form.

The first step of study is identified the Functional Analysis (Functional Analysis) which covers the main aim (Key Purpose), main role (Key Role), main function (Key Function) unit performance (Unit of Competence), performance sub (Element Competence), that consist of performance criteria (Performance Criteria), Scope (Range Statement), required evidence and proof of performance, evidence of knowledge (Evidence Requirement), and Evaluation (Assessment Guidance).

The methodology of the research also using the secondary document both the original research journal document and online resources together with the actual data from the discussion groups (focus group discussion-FGD) and experts concerned. Interviewing the respondents and participatory observation (participant observation), performance testing 
(assessment) analyzing career with mathematical tools (Functional analysis-FA) and structured interviews, (Unstructured questionnaire), observation (observation form) and test (assessment statement) are likewise used for data gathering.

The researchers used data collected from the respondents Such as Thai Authorize Custom Broker Association middle and senior management level include employee practices, including the confederation of associations and related logistics. Research technique used in-depth interviews and focus group interview. The data collection process from professional brokers of export and import of all products in Thailand.

\section{Research Results}

The results of the study realized that the implementation phase of the study details with the results of the study is as follows. The main aim (Key Purpose) is developing competencies in administering logistics of having the support of ASEAN and international merchandise exports by professional agents out of customs or Custom Broker or Shipping Agent main role of Export-Import as a main function (Key Function), thus the primary function is the management of import export to carry out customs clearance of export goods. Manager is expected to check the imports (Import) and carry out customs clearance of imported goods. Management of exports through its territory and Management of imported goods in transit are subject to trans-shipment cargo handling.

Research indicates that detailed performance units (Unit of Competence) offered is as follows:

(1). Units performance for handling exports and preparations include filing a petition to request a license to export from the Customs Department and ready preparation and coordination of export operations, customs clearing and delivery to the destination country.

(2). Units performance for handling imported goods consist of preparing the submission of a request for permission to import customs arrangements and coordination for imported goods. Customs and release of products offered for import.

(3). Units performance for handling export cargo is transit base. Preparation and coordination of export goods in transit and customs and release of goods in transit (cross border) operation of cargo crossings.

(4). Units performance for handling imported goods in transit include the preparation and coordination of imports. Goods in transit (cross border) Customs. And release of goods in transit.

(5). The performance management product for trans-shipment includes preparing and coordinating customs clearance documents trans-shipment operation and inspection of trans-shipment cargo.

(6). Performance of the sub-products for export includes documentation for registration as an export permit standard. AEO by the Customs Department approved the representation of customs procedures and prepare the checklist used by the customer in order to prepare for 
overseas export orders from customers in gather to prepare for implementation.

Each country provided detailed evidence on the merchandises exported in the port of entry with the approval of the export regulations of the Customs Department in coordination with the executing agency to provide merchandises that customers order. Packing orders related to exports is in order for a bank loan and coordinated flight vehicles and cargo for export. Coordinated and pre-arrange insurance for exports according to export customs clearance inspection documents are electronically coordinated with the freight company to ship to domestic output port set to monitor the status. Get cargo (Status 04), confirming the export success coordinated international logistics company to export products to international coordination insurers and to claim in case of damage.

(7). Performance subsidiaries (Element Competency) of the import product and preparation of documents for registration as an importer allowing standard of AEO approval by the Customs Department is the lead agency in accordance with regulation of customs documentation. Orders from manufacturers and selling to foreign origin and order tracking to gather and verify the authenticity of the document ordering. Consequently, checking vehicles imported track, date, time, place, and transport vehicles to carry documents for requesting permission to import from the relevant authorities and to check the authenticity of documents submitted to the authorities through the import permit to import goods. In checking the tax tariff benefits provided during inbound data entry via electronically to the Customs to check the receipt for payment of taxes, duties and other fees via e-Payment Document Delivery of goods. Import documents to be delivered to customers coordinate local freight companyfor shipment from the port imported into the client as required are prepared to claim the damage.

(8). Performance subsidiaries (Element of Competency) of import goods in transit contains documentation regarding the accounts of imported goods for the Kingdom. Accounting product shows detail to make the border crossing and prepare the vehicle license and vehicles pass going inside and outside of the Kingdom of Thailand. A Declaration to the border by Customs in the border for inspection of goods imported into the Kingdom of Thailand is necessary.

(9). Performance subsidiaries (Element of Competency) of export goods in transit. Include coordinating customer needs, allowing cargo transit through its territory to collect detailed documentation accounting for permission of goods carried in the vehicle to pass through the payment of duties and e-Payment settlement fees with the examination papers delivered through the controlled movement of cargo and through the assessment of duties, release of products through the supply trucks and employee transportation (Handling) to achieve the vehicle pass after the inspection of cargo goods through its territory.

(10). Performance subsidiaries (Element of Competency) of trans-shipment cargo handling and documentation consists of bill of lading for permission and trans-shipment cargo accounting of ships (Cargo. Manifest) for the purpose of permission to take the body to match the Bill of Lading prepared during declaration of trans-shipment required by the regulations of customs including tax payment before the goods to be delivered by the logistic cargo. The trans-shipment to vehicles Performance criteria (Performance Criteria) imports contains 
documentation request permission to export a standard AEO. With this regard, it has been prepared according to the procedures of customs documents, the request then will be approved through the exporters AEO standard which are prepared correctly according to the Customs Department. Coordination with the relevant authorities is to be requested by the representative of the customs procedures. Having been implemented correctly, the document requested by the broker will later be approved by the Customs Department to correctly catalog the foreign customers order. In checking correctly the catalog of the foreign customers order, exports are documentation and procurement are prepared correctly. Complete purchase orders have been collected in preparation for the implementation of export activities to every country destination. Moreover, export documents have been prepared in accordance with the purchase order document in manner of complete and export documentation. The preparation of the logistical information was accurate and complete according to the Customs Goods Declaration and export documentation. On the contrary, export activities have been reviewed properly by a customs specialist in documentation for export purposes.

(11). Performance subsidiaries (Element of Competency) of export goods in transit includes coordinating customer needs, allowing cargo transit through its territory to collect detailed documentation, accounting for permission to goods carried in the vehicle to pass through the payment of duties, e-Payment and settlement fees, examination papers delivered through the controlled movement of cargo through the assessment of duties, and release of products through the supply trucks and employee transportation (Handling) vehicle pass after the inspection of cargo goods through its territory.

(12). Performance subsidiaries (Element of Competency) of trans-shipment cargo handling and documentation consist of Bill of Lading for permission of trans-shipment cargo accounting of ships (Cargo. Manifest) and for permission to take the cargo to match the Lading Through Bill of Lading prepared by the declaration trans-shipment required by the regulations of customs tax payment before the goods is in transit to trans-shipment cargo expenses. The trans-shipment to vehicles Performance criteria (Performance Criteria) imports are contain of documentation requests and permission for export and standard AEO.

The shipment documentation has been prepared according to the procedures of customs documents. Likewise, the request is approved with exporters AEO standard and are prepared correctly according to the Customs Department. Coordination with the relevant authorities are relatively requested by the representative of the customs procedures. Having been implemented correctly, a document request broker may approve by the Customs Department to correctly catalog the foreign customers order. Checking correctly the catalog and the foreign customers order the exports are prepared in a correct order. Complete purchase orders have been collected in preparation for the implementation of exports to each country and correctly exporting documents have been prepared in accordance with the purchase order file. The port of entry both export and import are subject to formal customs documentation. The preparation of the information was assured with its accuracy, completeness, and according to the Customs Goods Declaration and export documentation standards. Export duties have been reviewed properly by a specialist customs documents for export and are prepared to bring a 
bank loan for payment. Complete bank loan documents are organized correctly to achieve the product delivery with the product information packaging that are exactly the type of product details. Completion and timely delivery is the goal to deliver the package correctly with the vehicle used to transport and prepare for shipment to the country of destination with correct vehicles used for transport. Goods delivered to the country of destination are reported to the main office for insurance documentation purposes to be done by the personnel of the Customs organization. As such, the schedule for this process is being done as a protocol prior to the delivery of the goods.

Performance criteria output comprises all the documentation requested by the customs department of quality control. By allowing the export standard AEO, the quality standard will be prepared according to the regulations of the Customs Department in coordination with the relevant authorities assigned. To request a representative of the customs procedures and to implement correctly the inspection of catalog to the customers in foreign orders every export transaction is prepared accurately to allow complete product orders are gathered in preparation for the implementation of exports for each country of destination. Correct export documents have been prepared in accordance with the purchase order document of the customers. Complete entry of export and export documentation are prepared to give information with accurate, complete data according to the Customs Department standard. Declaration of export documentation must be verified properly by specialists in the customs department. Documents for export are prepared to allow the grant of bank loan to accurately complete a bank loan documentation that is organized correctly. Product information and packaging is exactly the type of product that are Completed in a timely delivery. Packaging is correctly the order with vehicles used to transport to prepare the transport goods to the country of destination. The book presents the vehicles and cargo insurance can be coordinated prior to export effectively with policy that has been scheduled before exporting the product correctly. Clearance documents are electronically processed and checked is likewise duly coordinated the delivery from port of export to import. Performing correctly and effectively, reports on the coordination of international shipping are to be duly coordinated claims in case of damage done when correctly reported through effective coordination for damages claims.

In case of damage to the cargo it must be checked to track the status of the cargo to correctly get the cargo status and confirm the export success of the shipment.

Performance criteria (Performance Criteria) export of goods through its territory are customers who want to include allowing cargo transit that are contacted for details on obtaining permission to haul cargo crossings across the border of entrance. Complete documentation allowing cargo transit is preparing to collect details of the transit in its entirety of the transit process with documents regarding product accounts that are prepared for details, allowing the goods carried in the vehicle to pass accurately. Account documents and permit importation of goods carried in the vehicle to pass the checked-in are to correctly identify the goods in transit while being checked for accuracy before the tax payment via e-Payment and other fees are paid. Goods in transit and tax has been paid via e-Payment and other fees are paid accurately according to the document and delivery of goods exported. 
Through the preparation of accurate and complete delivery document export goods through its territory are checked for accuracy of moving cargo exported through the port of export that needs to be controlled properly. Fully moving cargo exported through the port of export customs must effectively control the release of goods that has been paid to this assessment is accurately complete in terms of tax payment and fees which is operated correctly with staff in terms of unloading supply trucks to transit vehicles for accurate operation. Documents with staff unloading supply trucks have been done correctly to check and inspect the goods after the cargo crossings. Complete and accurate documentation verifying inspection and condition monitoring to the products from the receiver will be checked correctly.

Performance criteria in manners of importing goods through the border town are being processed with right accounting for goods imported into the Kingdom of Thailand with the assistance from the bureau of customs. Declaration Accounts and Orders for approval to release the goods to customs are accurate and complete product details will be made through the account in order to correctly complete the details and check book requests with product correctly and completely checked ready for transit delivery. Vehicles pass into the Kingdom of Thailand must have duly licensed pass in any means of logistics. Vehicles pass into the Kingdom are being checked with their accuracy Declaration to the border prepared in accordance with the regulations of the Customs Transit Declaration which are correctly admissible to the inspection by the Customs in transit that can produce accurate and complete papers. In terms to the preparation for customs clearance the electronic system accurately detect the release of goods into the United States carried out correctly. According to the customs boundary (Range Statement) of management including import, the scope of the operation and other environmental conditions or other circumstances is having the impact on performance including equipment and technology resources used or other related terms that is included in the scope of work are as follows:

1). Check the catalog and prepare the goods by the customer in order to prepare for overseas export and import transaction correctly.

2). Gather orders from customers in preparation for the implementation of exports to each country with complete legal documentation.

3). Prepare detailed information on the products exported in accordance with the regulations of the Customs Export Declaration with completed approval by Customs department.

4). Coordinate with relevant agencies like bank loan transaction that has been completely accurate.

5). Arrange its payment and packing orders for export purposes.

6). Coordinate vehicles and cargo documentation for export and import protocols.

7). Coordinate and pre-arrange insurance for export customs regulations effective transaction.

The performance evidence for handling imported product consist of the ten items as 
following

1). A request for approval as a standard output for AEO.

2). Request document issued by the Customs Department.

3). Audit reports and prepare the goods for delivery.

4). Export Data for legal purposes.

5). Export Declaration by the Customs Department.

6). Documents for a bank loan legal purposes.

7). Packing List and order.

8). Requests for the vehicles and cargo.

9). Insurance process and documentation.

Evidence Requirement of management is export, import, including the training documentation for export and import. Certification and evaluation agency through training, documentation, export and import are necessary for quality assurance.

Evaluation (Assessment Guidance) to conduct assessment and evaluation tools used in the process to determine how to use and evaluate the guidelines in assessing the professional level and not at a higher level of at least 10 people, the evaluation of the training process with the professional competency standards Evaluation (Assessment Guidance) consists of a test or interview.

To provide a professional performance facts and documentation must be recognized by the general public that it was organized with the participation of the people's own career guidelines. The seminar examines public interest presented to the results of a professional standard and later the feedback of the respondents. By inviting the involvement of all sectors, entrepreneurs, qualified personnel and professional associations such as clubs, government agencies, and private organizations are generally joined together to at least 50 people to participate in recognition from all sectors. After obtaining the feedback from the public hearing and then prepare the assessment on the conduct of the research evaluation ethics, the tools used to evaluate a set of methods and tools to be used to evaluate the guidelines are assessed to the occupational standard. In the early levels and higher minimum standard career the evaluation is classified in three levels; which are professional level, the quality of the experts with not less than 3 trials to evaluate the performance of each level as defined in the qualification, professional career field goal The level of at least 10 people who are trained to evaluate the performance evaluation process to determine the level of professional qualification standards for Export and Import as following.

National Qualification Vocational Competence of Thai export-import operations of employee divided into seven levels as following

National Qualification Vocational Competence 1 are 
a. Registered for export. And Brokerage

b. Registration for imports And Brokerage

National Qualification Vocational Competence 2 are

a. preparation and coordination for the export and packaging process.

b. Delivery of goods for export.

c. Preparation and coordination for imported goods.

d. Delivery of goods for import.

e. Preparation and coordination of export. Goods in transit (cross border).

f. Prepare and coordinate import goods in transit (cross border).

g. Prepare for trans-shipment and coordination in the trans-shipment of imported goods.

National Qualification Vocational Competence level 3 are

a. Customs Clearance and product release.

b. verify export documents and release of goods in transit.

c. Customs Clearance And release of goods in transit.

National Qualification Vocational Competence level 4 are

a. Customs Clearance and release of goods in transit

National Qualification Vocational Competence level 5 are

a. carry out customs clearance and release of goods in transshipment cargo trans-shipment.

National Qualification Vocational Competence level 6 are

a. Customs Clearance and product release.

b. Verify export documents and the release of goods in transit.

c. Customs Clearance and release of goods in transit.

d. Customs Clearance and release of goods in transit.

e. carry out customs clearance and release of goods in trans-shipment and cargo trans-shipment.

National Qualification Vocational Competence level 7 are

a. Customs Clearance And product release.

b. Customs Clearance and product release.

c. Verify export documents and the release of goods in transit. 
d. Customs Clearance and release of goods in transit.

e. Customs Clearance and release of goods in transit.

f. Carry out customs clearance and release of goods in trans-shipment and cargo trans-shipment.

\section{Discussion and Conclusion}

The export-import occupational competencies study shows the level of professional qualification export and import competency. The contribution of research study is to implementation this competency standard for Thai export and import employee in term of national vocational qualification standard. The specification qualification enhance Thai standard of employee competence as same as the requirement of the global standard of competency. The advantages of this study is to increase the standard of export and import operation to support export and import company with occupation and develop employee's performance of the whole process of operation. Furthermore, the advantages of study is to encourage the relationship between Thai professional qualification vocational and curriculum design for student in export and import college and Faculty of commerce of all Thai universities. In the future, Thai education institute is to produce the graduate's student to support the requirement of export and import Company as well as developing logistic system to global vocational standard. With this regard, the notion should be increased collaboration with partners in the course of both sides which are the University in collaboration with the enterprises along with curriculum design which it will be truly useful. The training process also necessary for professional qualification

\section{References}

After the QCF: A New Qualifications Framework Decisions on Conditions and Guidance for the Regulated Qualifications Framework (RQF). (2015). [Online] Available: https://www.gov.uk/government/uploads/system/uploads/attachment_data/file/461401/after-t he-qcf-a-new-qualifications-framework-decisions-on-conditions-and-guidance-for-the-rqf.pdf

Blank, W. E. (1982). Handbook for Developing Competency-Based Training Programs. Englewood Cliffs, New Jersey: Prentice-Hall, Inc.

Fento (2002). NVQs in training and development level 3. In C. C. Pinder (Ed.), Work Motivation-Theory, Issues, and Applications. Glenview, Illinois: Scott, Foresman and Company.

Lloyd, C., \& Cook, A. (1993). Implementing Standards of Competence Practical Strategies for Industry. London: Kogan Page.

Ludlow, R., \& Panton, F. (1996). The Essence of Successful Staff Selection. Hertfordshire, U.K.: Prentice Hall International (UK) Ltd.

Resnick, R. B., \& Wirt, J. G. (1996). Linking School and Work-Roles for Standards and Assessment. San Francisco: Jossey-Bass Publishers. 


\section{Macrothink}

Case Studies in Business and Management

ISSN 2333-3324

2016, Vol. 3, No. 2

Salvendy, G. (2002). Handbook of Industrial Engineering-Productivity Measurement and Improvement. In M. E. Mundel (Ed.). New York: John Wiley \& Sons Inc.

U.S. Department of Labor. (1991). Dictionary of Occupational Titles, Volume I \& II (4th ed.). Washington, D.C: U.S. Employment Service.

Wood, R., Johnson, C., Blinkhorn, S., Anderson, S., \& Hall, J. (1989). Boning, Blanching and Backtracking: Assessing Performance in the Workplace. Sheffield: Training Agency.

\section{Copyright Disclaimer}

Copyright for this article is retained by the author(s), with first publication rights granted to the journal.

This is an open-access article distributed under the terms and conditions of the Creative Commons Attribution license (http://creativecommons.org/licenses/by/3.0/). 